
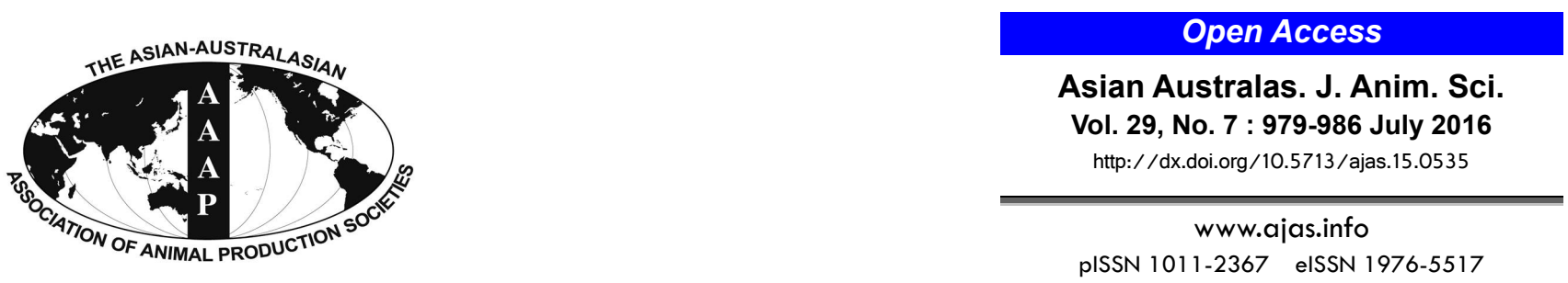

\title{
Supplementation of Dried Mealworm (Tenebrio molitor larva) on Growth Performance, Nutrient Digestibility and Blood Profiles in Weaning Pigs
}

\author{
X. H. Jin, P. S. Heo, J. S. Hong, N. J. Kim ${ }^{1}$, and Y. Y. Kim* \\ Department of Agricultural Biotechnology, College of Animal Life Sciences, \\ Seoul National University, Seoul 151-921, Korea
}

\begin{abstract}
This experiment was conducted to investigate the effects of dried mealworm (Tenebrio molitor larva) on growth performance, nutrient digestibility and blood profiles in weaning pigs. A total of 120 weaning pigs ( $28 \pm 3$ days and $8.04 \pm 0.08 \mathrm{~kg}$ of body weight) were allotted to one of five treatments, based on sex and body weight, in 6 replicates with 4 pigs per pen by a randomized complete block design. Supplementation level of dried mealworm was $0 \%, 1.5 \%, 3.0 \%, 4.5 \%$, or $6.0 \%$ in experimental diet as treatment. Two phase feeding programs (phase I from 0 day to 14 day, phase II from 14 day to 35 day) were used in this experiment. All animals were allowed to access diet and water ad libitum. During phase I, increasing level of dried mealworm in diet linearly improved the body weight $(p<0.01)$, average daily gain (ADG) $(p<0.01)$ and average daily feed intake (ADFI) $(p<0.01)$. During phase II, ADG also tended to increase linearly when pigs were fed higher level of dried mealworm $(p=0.08)$. In addition, increasing level of dried mealworm improved the ADG $(p<0.01)$, ADFI $(p<0.05)$ and tended to increase gain to feed ratio $(p=0.07)$ during the whole experimental period. As dried mealworm level was increased, nitrogen retention and digestibility of dry matter as well as crude protein were linearly increased $(p=0.05)$. In the results of blood profiles, decrease of blood urea nitrogen (linear, $p=0.05)$ and increase of insulin-like growth factor (linear, $\mathrm{p}=0.03$ ) were observed as dried mealworm was increased in diet during phase II. However, there were no significant differences in immunoglobulin A (IgA) and $\operatorname{IgG}$ concentration by addition of dried mealworm in the growth trial. Consequently, supplementation of dried mealworm up to $6 \%$ in weaning pigs' diet improves growth performance and nutrient digestibility without any detrimental effect on immune responses. (Key Words: Dried Mealworm, Growth Performance, Insect, Tenebrio molitor Larva, Weaning Pigs)
\end{abstract}

\section{INTRODUCTION}

More than 10 million of insect species have been identified, which account for a half of all creatures in earth. Among of them, approximately 1,500 species of insects are known to be an edible protein source for humans and animals $(\mathrm{Ng}, 2001)$. Edible insects contain higher protein content compared with plant protein, 18 kinds of amino acids including essential amino acids and vitamin and

\footnotetext{
* Corresponding Author: Y. Y. Kim. Tel: +82-2-878-5838, Fax:+82-2-878-5839, E-mail: yooykim@snu.ac.kr

${ }^{1}$ National Academy of Agricultural Science, Wanju 565-851, Korea.

Submitted Jun. 24, 2015; Revised Sept. 14, 2015; Accepted May 25, 2016
}

mineral properties that have been evaluated in detail (MacEvilly, 2000). Furthermore, insects have several useful physiological characteristics such as high efficiency reproductive ability, high feed conversion rate (or high conversion rate of organic matter), and easy rearing with low feed cost (Liu et al., 2010).

The Sánchez-Muros et al. (2014) also reported that edible insects were used as an alternative source of feed ingredients in the animal feed industry. From those reasons, insects have been proposed as a sustainable alternative protein source for animal feed.

The insect market for animal feed is continually increasing in the world, especially focused on Tenebrio molitor larva. Tenebrio molitor has been known to be an 
acceptable protein source in poultry diets (Ramos-Elorduy et al., 2002), and the nutritional value of Tenebrio molitor was also reported (Nergui et al., 2012).

Moreover, a few studies have been conducted to evaluate the application and large-scale production of Tenebrio molitor to supply the animal feed industry (Hernandez, 1987; Lagunes and Garcia, 1994). However, there is still lack of published data of the effects of dried mealworm on weaning pigs.

Therefore, the objective of this experiment was to investigate the effects of dried mealworm (Tenebrio molitor larva) supplementation as a protein source on growth performance, nutrient digestibility, and blood profiles in weaning pigs.

\section{MATERIALS AND METHODS}

\section{Experimental animal, treatment and diet}

A total of 120 crossbred ([Yorkshire $\times$ Landrace] $\times$ Duroc) weaning pigs ( $28 \pm 3 \mathrm{~d}$ of age, $8.04 \pm 0.08 \mathrm{~kg}$ body weight $[\mathrm{BW}]$ ) were assigned to one of five treatments considering sex and body weight in a randomized complete block design. Four pigs were reared in each pen of a weaning pigs' house (concrete-slot floor, $0.90 \times 2.15 \mathrm{~m}$ ). The control treatment group was provided with corn-barleysoybean meal-based diet and the other groups were provided with diet containing $1.5 \%, 3.0 \%, 4.5 \%$, or $6.0 \%$ of dried mealworm powder during 35 days after weaning. Feed and water were provided ad libitum through a feeder and a nipple during the whole experimental period. The temperature was kept at $30^{\circ} \mathrm{C}$ during the first 7 days and lowered $1{ }^{\circ} \mathrm{C}$ every week. An experimental period consists of two phases (Phase I: from 0 day to 14 day, Phase II: from 14 day to 35 day), and body weight and feed intake were recorded at the end of each phase to calculate average daily gain (ADG), average daily feed intake (ADFI) and gain to feed ratio (G:F ratio). Corn-barley-soybean meal-based experimental diets were formulated to contain dried mealworm at levels of $0 \%, 1.5 \%, 3.0 \%, 4.5 \%$, or $6.0 \%$. Dried mealworm powder replaced soybean meal (SBM). and soy oil because of the high energy and protein content in dried tenebrio molitor larva powder (metabolizable energy $5,258 \mathrm{kcal} / \mathrm{kg}$, crude protein [CP] $46.44 \%$ ). All nutrients of experimental diets met or slightly exceeded the nutrient requirements as specified by NRC (2012). Mealworms were harvested until approximate $70 \mathrm{~d}$ of age and the air-dried Tenebrio molitor larvae were obtained from National Institute of Agricultural Sciences (Wanju, Korea). Dried mealworms were ground wholly by grinder for mealworm powder type before mixing the experimental feed. Dried mealworm (dry matter [DM] basis) contained approximately $5.84 \%$ of moisture, $43.27 \%$ of CP, $32.93 \%$ of crude fat, $4.86 \%$ of crude ash, respectively. Amino acid and fatty acid composition of dried mealworm are showed in Table 1. Formulas and chemical compositions of experimental diets are presented in Table 2 and 3.

\section{Apparent total tract digestibility}

A total of 20 crossbred pigs $(10.05 \pm 0.98 \mathrm{~kg} \mathrm{BW})$ were assigned to individual metabolic crates and allotted to one of five treatments with 4 replicates in completely randomized design. Each pig was fed $200 \mathrm{~g}$ of phase II diet twice per day at 7:00 and 19:00, minimum level of feeding was $2 \%$ per body weight which was over 2 times the maintenance energy requirement (NRC, 1998). After 5 days adaptation period, a 5 day collection period was started with the addition of $1 \%$ chromium oxide in experimental diets as an initial marker. As a finishing marker, $1 \%$ ferric oxide was added in each experimental diet at 6th day of collection period. Collection of feces was started when the chromium

Table 1. Composition of total amino acid ${ }^{1}$ and fatty $\operatorname{acid}^{2}$ in dried mealworm larvae (dry matter bases)

\begin{tabular}{|c|c|}
\hline Items & $\%$ \\
\hline \multicolumn{2}{|c|}{ Total amino acid composition } \\
\hline Aspartic acid & 3.07 \\
\hline Threonine & 1.57 \\
\hline Serine & 1.86 \\
\hline Glutamic acid & 4.57 \\
\hline Glycine & 2.04 \\
\hline Alanine & 3.15 \\
\hline Valine & 3.14 \\
\hline Isoleucine & 1.39 \\
\hline Leucine & 2.81 \\
\hline Tyrosine & 2.63 \\
\hline Phenylalanine & 1.36 \\
\hline Lysine & 1.86 \\
\hline Histamine & 1.07 \\
\hline Arginine & 2.03 \\
\hline Proline & 2.23 \\
\hline Methionine & 0.54 \\
\hline Cysteine & 0.35 \\
\hline Total & 35.67 \\
\hline \multicolumn{2}{|c|}{ Fatty acid composition } \\
\hline $\mathrm{C} 14$ & 2.85 \\
\hline $\mathrm{C} 15$ & 7.10 \\
\hline $\mathrm{C} 16$ & 9.33 \\
\hline $\mathrm{C} 16: 1$ & 2.12 \\
\hline $\mathrm{C} 18$ & 2.40 \\
\hline $\mathrm{C} 18 \ln 9$ & 40.78 \\
\hline C18 2n6 & 33.58 \\
\hline C18 3n6 & 1.85 \\
\hline Total & 100.00 \\
\hline
\end{tabular}

${ }^{1}$ Analyzed by laboratory of animal nutrition and biochemistry, Seoul National University, Korea.

${ }^{2}$ Analyzed by laboratory of animal nutrition and biochemistry, Seoul National University, Korea. 
Table 2. The formula and chemical composition of experimental diets (phase I, d 0 to 14); as fed basis

\begin{tabular}{|c|c|c|c|c|c|}
\hline \multirow{2}{*}{ Items } & \multicolumn{5}{|c|}{ Tenebrio molitor larva (\%) } \\
\hline & 0 & 1.5 & 3.0 & 4.5 & 6.0 \\
\hline \multicolumn{6}{|l|}{$\begin{array}{l}\text { Ingredients }(\%) \\
\text { ( })\end{array}$} \\
\hline Corn & 30.95 & 31.03 & 31.02 & 31.05 & 31.04 \\
\hline Soy bean meal (44\%) & 35.10 & 33.34 & 31.51 & 29.80 & 28.01 \\
\hline Mealworm larva & 0.00 & 1.50 & 3.00 & 4.50 & 6.00 \\
\hline Whey powder & 3.00 & 3.00 & 3.00 & 3.00 & 3.00 \\
\hline Lactose & 12.00 & 12.00 & 12.00 & 12.00 & 12.00 \\
\hline Barley & 12.42 & 13.32 & 14.37 & 15.26 & 16.29 \\
\hline Soy-oil & 3.22 & 2.51 & 1.79 & 1.10 & 0.39 \\
\hline $\mathrm{MCP}$ & 1.22 & 1.22 & 1.20 & 1.20 & 1.20 \\
\hline Limestone & 0.94 & 0.94 & 0.94 & 0.96 & 0.96 \\
\hline L-lysine $\cdot \mathrm{HCl}$ & 0.40 & 0.39 & 0.39 & 0.39 & 0.38 \\
\hline DL-methionine & 0.40 & 0.39 & 0.39 & 0.39 & 0.39 \\
\hline Vit. Mix ${ }^{1}$ & 0.12 & 0.12 & 0.12 & 0.12 & 0.12 \\
\hline Min. $\operatorname{Mix}^{2}$ & 0.12 & 0.12 & 0.12 & 0.12 & 0.12 \\
\hline Salt & 0.20 & 0.20 & 0.20 & 0.20 & 0.20 \\
\hline Choline- $\mathrm{Cl}(25 \%)$ & 0.10 & 0.10 & 0.10 & 0.10 & 0.10 \\
\hline Zinc oxide & 0.10 & 0.10 & 0.10 & 0.10 & 0.10 \\
\hline Total & 100.00 & 100.00 & 100.00 & 100.00 & 100.00 \\
\hline \multicolumn{6}{|l|}{ Chemical composition } \\
\hline $\operatorname{ME}(\mathrm{kcal} / \mathrm{kg})^{3}$ & 3,400 & 3,400 & 3,400 & 3,400 & 3,400 \\
\hline Moisture $(\%)^{4}$ & 6.55 & 6.57 & 6.78 & 6.83 & 6.83 \\
\hline Crude protein $(\%)^{4}$ & 21.44 & 21.53 & 21.56 & 21.66 & 21.34 \\
\hline Ether extract $(\%)^{4}$ & 5.78 & 5.79 & 5.45 & 5.50 & 5.69 \\
\hline Crude ash $(\%)^{4}$ & 5.00 & 5.05 & 4.96 & 4.84 & 4.90 \\
\hline Total lysine $(\%)^{3}$ & 1.35 & 1.35 & 1.35 & 1.35 & 1.35 \\
\hline Total methionine $(\%)^{3}$ & 0.39 & 0.39 & 0.39 & 0.39 & 0.39 \\
\hline Total calcium $(\%)^{3}$ & 0.80 & 0.80 & 0.80 & 0.80 & 0.80 \\
\hline Total phosphorus $(\%)^{3}$ & 0.65 & 0.65 & 0.65 & 0.65 & 0.65 \\
\hline \multicolumn{6}{|c|}{$\begin{array}{l}\text { MCP, monocalcium phosphate; ME, metabolizable energy. } \\
{ }^{1} \text { Provided the following per kilogram of diet: vitamin A, } 8,000 \mathrm{IU} \text {; } \\
\text { vitamin } \mathrm{D}_{3}, 1,600 \mathrm{IU} \text {; vitamin E, } 32 \mathrm{IU} \text {; d-biotin, } 0.4 \mathrm{mg} \text {; riboflavin, } 3.2 \\
\mathrm{mg} \text {; calcium pantothenic acid, } 8 \mathrm{mg} \text {; niacin, } 16 \mathrm{mg} \text {; vitamin } \mathrm{B}_{12}, 12 \mathrm{mg} \text {; } \\
\text { vitamin } \mathrm{K}, 2.4 \mathrm{mg} \text {. }\end{array}$} \\
\hline
\end{tabular}

oxide appeared in the feces and kept until the appearance of ferric oxide in the feces. Urine samples were collected during collection period in plastic containers containing 50 $\mathrm{mL}$ of $4 \mathrm{~N} \mathrm{H}_{2} \mathrm{SO}_{4}$ to prevent evaporation of nitrogen prior to nitrogen retention analysis. Fecal and urinary samples were stored at $-20^{\circ} \mathrm{C}$ until the end of collection period and the feces were dried in a drying oven at $60^{\circ} \mathrm{C}$ for $72 \mathrm{~h}$ and then ground to $1 \mathrm{~mm}$ in a Wiley mill for chemical analysis including moisture, protein, fat, and ash contents by AOAC methods (1995).

\section{Blood sampling and analysis}

In each treatment, 6 pigs with average body weight were
Table 3. The formula and chemical composition of experimental diets (phase II, d 14 to 35); as fed basis

\begin{tabular}{|c|c|c|c|c|c|}
\hline \multirow{2}{*}{ Items } & \multicolumn{5}{|c|}{ Tenebrio molitor larva (\%) } \\
\hline & 0 & 1.5 & 3.0 & 4.5 & 6.0 \\
\hline \multicolumn{6}{|l|}{ Ingredients $(\%)$} \\
\hline Corn & 32.55 & 33.49 & 34.44 & 35.38 & 36.29 \\
\hline & 27.28 & 25.61 & 23.95 & 22.27 & 20.63 \\
\hline $\mathrm{Me}$ & 0.00 & 1.50 & 3.00 & 4.50 & 6.00 \\
\hline $\mathrm{Lac}$ & 4.00 & 4.00 & 4.00 & 4.00 & 4.00 \\
\hline & 30.00 & 30.00 & 30.00 & 30.00 & 30.00 \\
\hline & 42 & 2.65 & 1.87 & 1.10 & 0.34 \\
\hline MC & 1.03 & 1.00 & 1.01 & 1.00 & 1.00 \\
\hline & 0.66 & 0.69 & 0.68 & 0.70 & 0.71 \\
\hline & 43 & 0.43 & 0.42 & 0.42 & 0.41 \\
\hline DL-n & 0.09 & 0.09 & 0.09 & 0.09 & 0.08 \\
\hline Vit. & 0.12 & 0.12 & 0.12 & 0.12 & 0.12 \\
\hline Min. I & 0.12 & 0.12 & 0.12 & 0.12 & 0.12 \\
\hline Salt & 0.20 & 0.20 & 0.20 & 0.20 & 0.20 \\
\hline $\mathrm{Ch}$ & 10 & 0.10 & 0.10 & 0.10 & 0.10 \\
\hline Total & 100.00 & 100.00 & 100.00 & 100.00 & 100.0 \\
\hline \multicolumn{6}{|l|}{ Chemical composition } \\
\hline $\operatorname{ME}(\mathrm{kcal} / \mathrm{kg})^{3}$ & 3,350 & 3,350 & 3,350 & 3,350 & 3,350 \\
\hline Mois & 9.23 & 9.61 & 9.37 & 9.25 & 8.66 \\
\hline Crude protein $(\%)^{4}$ & 18.99 & 18.31 & 18.86 & 18.68 & 18.32 \\
\hline Eth & 5.63 & 5.60 & 5.71 & 5.65 & 5.58 \\
\hline Crude ash $(\%)^{4}$ & 4.38 & 4.24 & 4.28 & 4.26 & 4.24 \\
\hline Total & 1.23 & 1.23 & 1.23 & 1.23 & 1.23 \\
\hline Total $n$ & 0.36 & 0.36 & 0.36 & 0.36 & 0.36 \\
\hline Total calcium $(\%)^{3}$ & 0.70 & 0.70 & 0.70 & 0.70 & 0.70 \\
\hline Total phosphorus $(\%)^{3}$ & 0.60 & 0.60 & 0.60 & 0.60 & 0.60 \\
\hline \multicolumn{6}{|c|}{$\begin{array}{l}\text { MCP, monocalcium phosphate; ME, metabolizable energy. } \\
1 \text { Provided the following per kilogram of diet: vitamin A, 8,000 IU; } \\
\text { vitamin } \mathrm{D}_{3}, 1,600 \mathrm{IU} \text {; vitamin E, } 32 \mathrm{IU} \text {; d-biotin, } 0.4 \mathrm{mg} \text {; riboflavin, } 3.2 \\
\mathrm{mg} \text {; calcium pantothenic acid, } 8 \mathrm{mg} \text {; niacin, } 16 \mathrm{mg} \text {; vitamin } \mathrm{B}_{12}, 12 \mathrm{mg} \text {; } \\
\text { vitamin } \mathrm{K}, 2.4 \mathrm{mg} \text {. }\end{array}$} \\
\hline \multicolumn{6}{|c|}{$\begin{array}{l}{ }^{2} \text { Provided the following per kilogram of diet: } \mathrm{Mn}, 24.8 \mathrm{mg} \text {; } \mathrm{CuSO}_{4}, 54.1 \\
\mathrm{mg} \text {; Fe, } 127.3 \mathrm{mg} ; \mathrm{Zn}, 84.7 \mathrm{mg} \text {; Co, } 0.3 \mathrm{mg} ; \mathrm{Se}, 0.1 \mathrm{mg} ; \mathrm{I}, 0.3 \mathrm{mg} . \\
{ }^{3} \text { Calculated value. } \\
{ }^{4} \text { Analyzed value. }\end{array}$} \\
\hline
\end{tabular}

bled through the anterior vena cava to analyze blood urea nitrogen (BUN), insulin-like growth factor (IGF-1) and immune response (IgA, $\operatorname{IgG}$ ) at initial day and the ends of phases (phase I and phase II). Blood samples were collected in disposable culture tubes and centrifuged for $15 \mathrm{~min}$ by $3,000 \mathrm{rpm}$ at $4^{\circ} \mathrm{C}$ (Eppendorf centrifuge 5810R, Hamburg, Germany). The serum was carefully transferred to $1.5 \mathrm{~mL}$ micro tubes and stored at $-20^{\circ} \mathrm{C}$ until analysis. Total BUN concentration was analyzed using an analyzer (CibaCorning model, Express Plus, Ciba Corning diagnostics Co., Basel, Switzerland). The immunoglobulin G (IgG) and immunoglobulin A (IgA) concentration were analyzed by enzyme-linked immunosorbent assay (ELISA) assay by the manufacture's protocols (ELISA Starter Accessory Package, Pig IgG ELISA Quantitation Kit, Pig IgA ELISA 
Quantitation Kit; Bethyl, Montgomery, TX, USA). The concentration of IGF-1 was analyzed by hormone analyzer (Immulite 2000, DPC, Malvern, PA, USA).

\section{Chemical analysis}

Diets and feces were ground by a Cyclotec 1093 Sample Mill (Foss Tecator, Hillerod, Denmark) and then analyzed. The contents of DM (procedure 967.03; AOAC, 1995), ash (procedure 923.03; AOAC, 1995). The nitrogen content was analyzed by using the Kjeldahl procedure with Kjeltec (KjeltecTM 2200, Foss Tecator, Höganäs, Sweden) and calculating the $\mathrm{CP}$ content (Nitrogen $\times 6.25$; procedure 981.10; AOAC, 1995).

\section{Statistical analysis}

Statistical analysis was carried out by least squares mean comparisons using PDIFF option of general linear model procedure (SAS, 2002; SAS Inst. Inc., Cary, NC, USA). Each pen was considered as experimental unit in measuring growth performance, while individual pig was used as experimental unit for analyzing nutrient digestibility, nitrogen retention and blood characteristics. Orthogonal polynomial contrasts were performed to determine linear and quadratic effects of inclusion levels of dried mealworm. Statistical differences were considered highly significant differ at $\mathrm{p}<0.01$, significant differ at $\mathrm{p}<0.05$, tendency between $\mathrm{p} \geq 0.05$ and $\mathrm{p} \leq 0.10$.

\section{RESULTS}

The effects of supplementation of dried mealworm on growth performance in weaning pigs are presented in Table 4. Increasing dried mealworm level in weaning pig's diet significantly increased the body weight at end of phase I and phase II (linear, $\mathrm{p}<0.01$ ). During phase I, ADG and ADFI were linearly increased as dried mealworm level increased in diet (linear, $\mathrm{p}<0.01$ ). During Phase II (14 to 35 th day), increasing dried mealworm in weaning pig diet tended to improve the ADG of pigs (linear, $\mathrm{p}=0.08$ ), but ADFI was not altered by addition of dried mealworm. Although, significant improvement was not observed in G:F ratio during phase I and phase II, increasing dried mealworm level in diet resulted in a tendency of improvement to $\mathrm{G}: \mathrm{F}$ ratio during overall experimental period (linear, $\mathrm{p}<0.07$ ).

Addition of dried mealworm in weaning pigs' diet showed improvements of nutrient digestibility and nitrogen retention (Table 5). There were linear improvements in DM (linear, $p=0.05$ ) and CP (linear, $p=0.05$ ) digestibility by increasing levels of dried mealworm, and crude ash digestibility showed tendency of improvement by dried mealworm as well (linear, $\mathrm{p}=0.06$ ). In nitrogen retention, pigs fed a higher amount of dried mealworm showed a reduction of nitrogen excretion through feces (linear, $\mathrm{p}=$ 0.05), which resulted in a linear increase in nitrogen retention (linear, $\mathrm{p}=0.05$ ).

Changes of BUN, serum IGF-1, and serum immunoglobulins concentration by the addition of dried mealworm during the feeding trial are presented in Table 6 and 7. Increasing level of dried mealworm in diet linearly decreased BUN concentration at $35 \mathrm{~d}$ after weaning (linear, $\mathrm{p}<0.05$ ), and a similar decreasing tendency was observed at

Table 4. Effect of dried mealworm larvae supplementation on growth performance in weaning pigs ${ }^{1,2}$

\begin{tabular}{|c|c|c|c|c|c|c|c|c|}
\hline \multirow{2}{*}{ Criteria } & \multicolumn{5}{|c|}{ Tenebrio molitor larva (\%) } & \multirow{2}{*}{ SEM } & \multicolumn{2}{|c|}{$\mathrm{p}$-value } \\
\hline & 0 & 1.5 & 3.0 & 4.5 & 6.0 & & Lin. & Quad. \\
\hline \multicolumn{9}{|c|}{ Body weight (kg) } \\
\hline Initial & 8.05 & 8.04 & 8.05 & 8.04 & 8.04 & - & - & - \\
\hline 2 week & 9.63 & 9.80 & 10.01 & 10.51 & 10.66 & 0.310 & 0.01 & 0.83 \\
\hline 5 week & 17.78 & 18.34 & 19.10 & 19.77 & 20.22 & 0.531 & 0.01 & 0.90 \\
\hline \multicolumn{9}{|c|}{ Average daily gain (g) } \\
\hline $0-2$ week & 113 & 126 & 140 & 176 & 188 & 11.6 & 0.01 & 0.81 \\
\hline $2-5$ week & 388 & 407 & 433 & 441 & 455 & 15.2 & 0.08 & 0.82 \\
\hline Overall & 278 & 294 & 316 & 335 & 348 & 11.0 & 0.01 & 0.91 \\
\hline \multicolumn{9}{|c|}{ Average daily feed intake (g) } \\
\hline $0-2$ week & 250 & 270 & 283 & 336 & 349 & 13.3 & 0.01 & 0.77 \\
\hline $2-5$ week & 721 & 736 & 754 & 753 & 773 & 25.4 & 0.44 & 0.96 \\
\hline Overall & 532 & 550 & 566 & 586 & 604 & 17.3 & 0.05 & 0.96 \\
\hline \multicolumn{9}{|c|}{ Gain:feed ratio } \\
\hline $0-2$ week & 0.452 & 0.467 & 0.495 & 0.524 & 0.539 & 0.028 & 0.25 & 0.28 \\
\hline $2-5$ week & 0.539 & 0.552 & 0.575 & 0.586 & 0.589 & 0.015 & 0.24 & 0.89 \\
\hline Overall & 0.521 & 0.538 & 0.565 & 0.573 & 0.576 & 0.011 & 0.07 & 0.62 \\
\hline
\end{tabular}

SEM, standard error of mean.

${ }^{1}$ A total of 120 crossbred pigs were fed from average initial body weight $8.04 \pm 0.08 \mathrm{~kg}$.

${ }^{2}$ Each least squares mean for all treatments represents 6 observations respectively. 
Table 5. Effect of dried mealworm larvae supplementation on nutrient digestibility in weaning pigs ${ }^{1,2}$

\begin{tabular}{|c|c|c|c|c|c|c|c|c|}
\hline \multirow{2}{*}{ Criteria } & \multicolumn{5}{|c|}{ Tenebrio molitor larva (\%) } & \multirow{2}{*}{ SEM } & \multicolumn{2}{|c|}{ p-value } \\
\hline & 0 & 1.5 & 3.0 & 4.5 & 6.0 & & Lin. & Quad. \\
\hline \multicolumn{9}{|c|}{ Nutrient digestibility (\%) } \\
\hline Dry matter & 90.13 & 92.33 & 92.93 & 93.80 & 94.22 & 0.715 & 0.05 & 0.53 \\
\hline Crude protein & 86.29 & 90.25 & 91.27 & 92.17 & 93.04 & 1.141 & 0.05 & 0.47 \\
\hline Crude ash & 67.62 & 67.17 & 71.11 & 72.20 & 76.01 & 1.841 & 0.06 & 0.66 \\
\hline Crude fat & 81.40 & 81.67 & 82.96 & 82.79 & 81.55 & 1.328 & 0.87 & 0.65 \\
\hline \multicolumn{9}{|l|}{ N-retention $(\mathrm{g} / \mathrm{d})$} \\
\hline $\mathrm{N}$-intake & 5.30 & 5.34 & 5.34 & 5.31 & 5.36 & - & - & - \\
\hline $\mathrm{N}$-feces & 0.73 & 0.52 & 0.47 & 0.42 & 0.37 & 0.060 & 0.05 & 0.48 \\
\hline N-urine & 2.37 & 2.55 & 2.55 & 2.51 & 2.56 & 0.155 & 0.80 & 0.85 \\
\hline N-retention & 2.20 & 2.27 & 2.33 & 2.38 & 2.42 & 0.156 & 0.05 & 0.98 \\
\hline
\end{tabular}

SEM, standard error of mean.

${ }^{1} \mathrm{~A}$ total of 20 crossbred pigs were fed from average initial body weight $10.05 \pm 0.98 \mathrm{~kg}$.

${ }^{2}$ Least squares means of 4 observations per treatment.

$14 \mathrm{~d}$ after weaning (linear, $\mathrm{p}=0.08$ ). In contrast to BUN concentration, linear increase of serum IGF-1 concentration was observed at 35 th day when dried mealworm was increased in diet (linear, $\mathrm{p}<0.05$ ). However, increase of dried mealworm in diet did not alter serum immunoglobulins.

\section{DISCUSSION}

Studies using dietary insects as feed ingredient were mostly focused on poultry nutrition, and showed that using insect as a protein source in poultry diets had positive effects on growth performance (Téguia et al., 2002; Awoniyi et al., 2003; Shen et al., 2006). However, little information is available about using insect as a protein source in pig diets (Ni and Tang, 1993; Zhang and Zhou, 2002).

In general, pigs have to adapt rapid changes in feed with low enzyme activity after weaning (Jensen et al., 1997). Therefore, the composition of the starter diet after weaning requires highly digestible ingredients to avoid growth check or high mortality from weaning stress (Mahan and Newton, 1993). Although animal-origin protein sources' price is more expensive, it is widely utilized in weaning pigs' diet rather than soybean meal or other plant-derived ingredients (Evans and Leibholz, 1979; Stoner et al., 1990; Kats et al., 1994). Beneficial effects of dried mealworm as feed ingredients have rarely been explored, but using other insect larvae as protein sources in swine feed has been evaluated by several studies. Huang and Zhang (1984) reported that

Table 7. Effect of dried mealworm larvae supplementation on serum IgG and IgA concentration in weaning pigs ${ }^{1}$

\begin{tabular}{|c|c|c|c|c|c|c|c|c|}
\hline \multirow{2}{*}{ Criteria } & \multicolumn{5}{|c|}{ Tenebrio molitor larva (\%) } & \multirow{2}{*}{ SEM } & \multicolumn{2}{|c|}{ p-value } \\
\hline & 0 & 1.5 & 3.0 & 4.5 & 6.0 & & Lin. & Quad. \\
\hline \multicolumn{9}{|c|}{$\overline{\mathrm{IgG}(\mathrm{mg} / \mathrm{mL})}$} \\
\hline Initial & 2.09 & 2.09 & 2.09 & 2.09 & 2.09 & - & - & - \\
\hline 2 week & 1.89 & 2.04 & 1.93 & 2.18 & 2.11 & 0.102 & 0.20 & 0.91 \\
\hline 5 week & 4.56 & 4.43 & 4.54 & 4.50 & 4.45 & 0.309 & 0.90 & 0.25 \\
\hline \multicolumn{9}{|c|}{$\operatorname{IgA}(\mathrm{mg} / \mathrm{mL})$} \\
\hline Initial & 1.29 & 1.29 & 1.29 & 1.29 & 1.29 & - & - & - \\
\hline $2 v$ & 1.47 & 1.60 & 1.55 & 1.63 & 1.56 & 0.069 & 0.15 & 0.96 \\
\hline 5 week & 2.48 & 2.34 & 2.41 & 2.39 & 2.52 & 0.154 & 0.95 & 0.93 \\
\hline
\end{tabular}

IgG, immunoglobulin G; IgA, immunoglobulin A; SEM, standard error of mean.

${ }^{1}$ Least squares means of 6 observations per treatment.

Table 6. Effect of dried mealworm larvae supplementation on BUN and IGF-1 in weaning pigs ${ }^{1}$

\begin{tabular}{|c|c|c|c|c|c|c|c|c|}
\hline \multirow{2}{*}{ Criteria } & \multicolumn{5}{|c|}{ Tenebrio molitor larva (\%) } & \multirow{2}{*}{ SEM } & \multicolumn{2}{|c|}{ p-value } \\
\hline & 0 & 1.5 & 3.0 & 4.5 & 6.0 & & Lin. & Quad. \\
\hline \multicolumn{9}{|c|}{ BUN (mg/dL) } \\
\hline Initial & 9.40 & 9.40 & 9.40 & 9.40 & 9.40 & - & - & - \\
\hline 2 week & 14.87 & 14.27 & 12.15 & 12.03 & 12.08 & 0.617 & 0.08 & 0.52 \\
\hline 5 week & 12.02 & 11.12 & 10.85 & 10.32 & 10.28 & 0.658 & 0.05 & 0.85 \\
\hline \multicolumn{9}{|c|}{ IGF-1 (ng/mL) } \\
\hline Initial & 75.12 & 75.12 & 75.12 & 75.12 & 75.12 & - & - & - \\
\hline 2 week & 83.77 & 87.77 & 86.10 & 87.13 & 93.08 & 3.169 & 0.37 & 0.78 \\
\hline 5 week & 107.67 & 123.00 & 129.58 & 131.48 & 136.34 & 4.007 & 0.03 & 0.44 \\
\hline
\end{tabular}

BUN, blood urea nitrogen; IGF-1, insulin-like growth factor-1; SEM, standard error of mean.

${ }^{1}$ Least squares means of 6 observations per treatment. 
feeding diet containing maggot meal in weaning pigs' diet increased weight gain by $3.5 \%$ and reduced production cost by $13.2 \%$ compared to diet containing fish meal. Zhang and Zhou (2002) presented evidence that silkworm fed growthfinishing pigs could increase ADG by $23.6 \%$ and shorten the finishing period. In case of Tenebrio molitor studies, Chen et al. (2012) reported that increasing Tenebrio molitor protein concentrate up to $6 \%$ in weaning pig diets linearly improved body weight and body weight gain. Although current study used full-fat Tenebrio molitor larva, the results showed that dietary Tenebrio molitor have benefits as a protein source for weaning pigs. Moreover, improvement of ADFI by increasing the amount of Tenebrio molitor larvae in current study demonstrated that the flavor of Tenebrio molitor improved the palatability of diet and increased feed intake in weaning pigs.

In the present study, increasing level of dried mealworm in weaning pigs' diet improved DM digestibility. Improving growth performance with mealworm can be explained with current result of nutrients digestibility. Animal protein sources have better availability compared to plant-derived protein sources because of the balanced amino acid composition in animal protein (Cromwell, 1998). Nergui et al. (2012) represented that mealworm had various kinds of amino acids and their composition met the requirements of domestic animals. Newton et al. (1977) reported that addition of black soldier fly larvae in pig diet showed similar apparent CP digestibility as soybean meal, and Hwangbo and Hong (2009) demonstrated that broilers fed diet containing 30\% housefly larvae meal had a higher apparent $\mathrm{CP}$ and amino acid digestibility than that of broilers fed basal diet. In addition, larvae accumulate lipids in their body which contain high levels of energy to meet their energy requirement in the pupal stage. Therefore, addition of Tenebrio molitor larvae in the diet caused a decrease in the amount of soy oil added in the present study. In contrast to animal protein sources, plant derived fat sources generally have better bioavailability than animal derived fats in young pigs because plant oil contains a high proportion of unsaturated fatty acid (Overland et al., 1996; Smith et al., 1996; Van Oeckel et al., 1996; Leskanich et al., 1997). Furthermore, Newton et al. (1977) demonstrated that black soldier fly larvae had higher fat digestibility than that of SBM and Finke (2002) represented that Tenebrio molitor larvae contained high levels of unsaturated fatty acid and had suitable unsaturated fatty acid:saturated fatty acid ratio which may have resulted in the maintenance of fat digestibility as did the replacement of soy oil with mealworm powder in current study.

Serum IGF-1 and BUN concentration are affected by the nutritional status of the animal, and have been used to predict the trends of growth and nutrient digestibility (Eggum, 1970; Etherton et al., 1987). The IGF-1 as growth hormone plays an important role in controlling the structure, function of cardiovascular system and skeletal maturation (Bayes-genis et al., 2000). Current study showed that supplemented dried mealworm stimulated the IGF-1 secretion and it had a positive influence on growth and feed efficiency. High level of BUN indicated that excessive amino acids were metabolized and circulated in the blood (Malmolf, 1988). Therefore, BUN concentration can be considered as an indicator for measurement of protein property and amino acid availability by animals (Eggum, 1970). In current study, BUN concentration had a tendency to decrease linearly as supplementation level of dried mealworm powder increased on 2 week and 5 week (linear, $\mathrm{p}=0.08,0.05)$. These results in the current study corresponded to the growth performance that improved BW and ADG with the improved nitrogen retention of nutrient digestibility.

Chitin may have a positive effect on the functioning of the immune system (Lee et al., 2008; Sánchez-Muros et al., 2014) and it could improve the immune status of the animals (Harikrishnan et al., 2012). Yuanqing et al. (2013) recommended $500 \mathrm{mg} / \mathrm{kg}$ of chitosan as an antibiotic substitute in weaning pigs. Huang et al. (2005) reported that supplementation $100 \mathrm{mg} / \mathrm{kg}$ of chitosan oligosaccharide improved ADG and ileal digestibility in broilers. In current study, Tenebrio molitor larva had $11.56 \mathrm{mg} / \mathrm{g}$ of chitosan (not suggested in tables) and larvae in the 6\% treatment contained $0.07 \%$ of chitosan in experimental diet. On the other hand, some researchers demonstrated that using insects should increase edible safety because insects also contained chemical defense substances as toxin produced by exocrine gland (Wang et al., 2001). Mealworm has been known to contain benzoquinone as a toxin which is secreted by defensive gland of Tenebrio moilor (Attygalle et al., 1991) However, supplementation of dried mealworm did not have significant effects on blood IgG and IgA concentration as immune response.

\section{CONCLUSION}

Inclusion of dried mealworm (Tenebrio molitor larvae) up to $6 \%$ in weaning pig's diet is beneficial for weaning pigs by improvement of growth performance. Dried mealworm supplementation increased feed intake and nutrient digestibility without any detrimental effect on immune response. Dried mealworm powder is available as protein source for weaning pigs' diet.

\section{CONFLICT OF INTEREST}

We certify that there is no conflict of interest with any financial organization regarding the material discussed in the manuscript. 


\section{ACKNOWLEDGMENTS}

This research was supported by "Cooperative Research Program for Agriculture Science and Technology Development (Project No. PJ009226)" Rural Development Administration, Republic of Korea.

\section{REFERENCES}

AOAC. 1995. Official Methods of Analysis. 16th edn. Association of Official Analytical Chemists, Arlington, VA, USA.

Attygalle, A. B., C. L. Blankespoor, J. Meinwald, and T. Eisner. 1991. Defensive secretion of Tenebrio molitor (Coleoptera: Tenebrionidae). J. Chem. Ecol. 17:805-809.

Awoniyi, T. A. M., V. A. Aletor, and J. M. AIna. 2003. Performance of broiler-chickens fed on maggot meal in place of fishmeal. Int. J. Poult. Sci. 2:271-274.

Bayes-Genis, A., C. A. Conover, and R. S. Schwartz. 2000. The insulin-like growth factor axis: a review of atherosclerosis and restenosis. Circ. Res. 86:125-130.

Chen, Z. B. 2012. Analysis for nutritional value of four kinds of insects and use of Tenebrio molitor power in weaning pig production. China Knowledge Resource Integrated Database (CNKI), Shandong Agricultural University, Shandong, China.

Cromwell, G. L. 1998. Feeding swine. In: Livestock Feeds and Feeding. 4th ed. Prentice-Hall, Upper Saddle River, NJ, USA. $354 \mathrm{p}$.

Eggum, B. O. 1970. Blood urea measurement as a technique for assessing protein quality. Br. J. Nutr. 24:983-988.

Etherton, T. D., J. P. Wiggins, C. M. Evock, C. S. Chung, J. F. Rebhun, P. E. Walton, and N. C. Steele. 1987. Stimulation of pig growth performance by porcine growth hormone: determination of the dose-response relationship. J. Anim. Sci. 64:433-443.

Evans, D. F. and J. Leibholz. 1979. Meat meal in the diet of the early-weaned pig. I. A comparison of meat meal and soya bean meal. Anim. Feed Sci. Technol. 4:33-42.

Finke, M. D. 2002. Complete nutrient composition of commercially raised invertebrates used as food for insectivores. Zoo Biol. 21:269-285.

Harikrishnan, R., J. S. Kim, C. Balasundaram, and M. S. Heo. 2012. Dietary supplementation with chitin and chitosan on haematology and innate immune response in Epinephelus bruneus against Philasterides dicentrarchi. Exp. Parasitol. 131:116-124.

Hernandez, C. 1987. Elaboration of a sweet yellow mealworm T. molitor (Coleoptera: Tenebrionidae). Thesis. University of Quimica, Auton, Mexico.

Huang, Z. Z. and N. Z. Zhang. 1984. Development of new source of protein feed - rearing maggots. Feed Res. 1987:17-21.

Huang, R. L., Y. L. Yin, G. Y. Wu, Y. G. Zhang, T. J. Li, L. L. Li, M. X. Li, Z. R. Tang, J. Zhang, B. Wang, J. H. He, and X. Z. Nie. 2005. Effect of dietary oligochitosan supplementation on ileal digestibility of nutrients and performance in broilers. Poult. Sci. 84:1383-1388.

Hwangbo, J. and E. C. Hong. 2009. Utilization of house flymaggots, a feed supplement in the production of broiler chickens. J. Environ. Biol. 30:609-614.
Jensen, M. S., S. K. Jensen, and K. Jakobsen. 1997. Development of digestive enzymes in pigs with emphasis on lipolytic activity in the stomach and pancreas. J. Anim. Sci. 75:437-445.

Kats, L. J., J. L. Nelssen, M. D. Tokach, R. D. Goodband, T. L. Weeden, S. S. Dritz, J. A. Hansen, and K. G. Friesen. 1994. The effects of spray-dried blood meal on growth performance of the early-weaned pig. J. Anim. Sci. 72:2860-2869.

Lagunes, L. A. and L. Garcia. 1994. Two Insects Productivity Obtained by Recycling of Organics Made of Animal and Vegetable. Ph. M. Thesis, University of Ciencia, Auton, Mexico.

Lee, C. G., C. A. Da Silva., J. Y. Lee., D. Hartl, and J. A. Elias. 2008. Chitin regulation of immune responses: an old molecule with new roles. Curr. Opin. Immunol. 20:684-689.

Leskanich, C. O., K. R. Matthews, C. C. Warkup, R. C. Noble, and M. Hazzledine. 1997. The effect of dietary oil containing (n-3) fatty acids on the fatty acid, physiochemical, and organoleptic characteristics of pig meat and fat. J. Anim. Sci. 75:673-683.

Liu, Y. S., F. B. Wang., J. X. Cui, and L. Zhang. 2010. Recent status and advances on study and utilization of Tenebrio molitor. J. Environ. Entomol. 32:106-114.

MacEvilly, C. 2000. Bugs in the system. Nutr. Bull. 25:267-268.

Mahan, D. C. and E. A. Newton. 1993. Evaluation of feed grains with dried skim milk and added carbohydrate sources on weanling pig performance. J. Anim. Sci. 71:3376-3382.

Malmolf, K. 1988. Amino acid in farm animal nutrition metabolism, partition and consequences of imbalance. J. Agric. Res. 18:191-193.

Newton, G. L., C. V. Booram, R. W. Barker, and O. M. Hale. 1977. Dried Hermetia illucens larvae meal as a supplement for swine. J. Anim. Sci. 44:395-400.

Ng, W. K., F. L. Liew, L. P. Ang, and K. W. Wong. 2001. Potential of mealworm (Tenebrio molitor) as an alternative protein source in practical diets for African catfish, Clarias gariepinus. Aquac. Res. 32:273-280.

Ni, X. J. and G. J. Tang. 1993. Evaluation of optimal silkworm supplementation in suckling piglets diet. ZheJiang J. Anim. Sci. Vet. Med. 3:49-49.

NRC. 1998. Nutrient Requirements of Swine. 10th Ed. National Academy Press, Washington, DC, USA.

NRC. 2012. Nutrient Requirements of Swine. 11th Ed. National Academy Press. Washington, DC, USA.

Overland, M., O. Taugbol, A. Haug, and E. Sundstol. 1996. Effect of fish oil on growth performance, carcass characteristics, sensory parameters, and fatty acid composition in pigs. Acta Agric. Scand. Anim. Sci. 46:11-17.

Ramos-Elorduy, J., E. A. Gonzalez., A. R. Hernandez, and J. M. Pino. 2002. Use of Tenebrio molitor (Coleoptera: Tenebrionidae) to recycle organic wastes and as feed for broiler chickens. J. Econ. Entomol. 95:214-220.

Ravzanaadii, N., S. H. Kim, W. H. Choi, S. J. Hong, and N. J. Kim. 2012. Nutritional Value of Mealworm, Tenebrio molitor as Food Source. Int. J. Indust. Entomol. 25:93-98.

Sánchez-Muros, M. J., F. G. Barroso, and F. Manzano-Agugliaro. 2014. Insect meal as renewable source of food for animal feeding: A review. J. Cleaner Prod. 65:16-27.

SAS Institute, 2002. SAS/STAT User's Guide: Version 9.1. SAS Institute, Cary, NC, USA.

Shen, H., X. L. Pan, and J. G. Wang. 2006. Effect of Tenebrio 
molitor L. supplementation on growth performance and protein deposition in broilers. Heilongjiang Anim. Vet. Sci. 2006(08):61-62.

Smith, D. R., D. A. Knabe, and S. B. Smith. 1996. Depression of lipogenesis in swine adipose tissue by specific dietary fatty acids. J. Anim. Sci. 74:975-983.

Stoner, G. R., G. L. Allee, J. L. Nelssen, M. E. Johnston, and R. D. Goodband. 1990. Effect of select menhaden fish meal in starter diets for pigs. J. Anim. Sci. 68:2729-2735.

Téguia, A., M. Mpoame, and J. O. Mba. 2002. The production performance of broiler birds as affected by the replacement of fish meal by maggot meal in the starter and finisher diets. Tropicultura 20:187-192.
Van Oeckel, M. J., M. Casteels, N. Warnants, L. Van Damme, and Ch. V. Boucque. 1996. Omega-3 fatty acids in pig nutrition: implications for the intrinsic and sensory quality of the meat. Meat Sci. 44:55-63.

Wang, X. P., C. L. Lei, and C. Y. Niu. 2001. The defensive secretion from insects. Institute of insect sources, Huazhong Agricultural University, Wuhan, China.

Yuanqing, X., S. Binlin, G. Yiwei, L. Tiyu, L. Junliang, Y. Ping, and G. Xiaoyu. 2013. Effects of chitosan on the development of immune organs and gastrointestinal tracts in weaned piglets. Feed Ind. 3:008.

Zhang, J. H. and E. F. Zhou. 2002. Feed Resource and Utilization. China agriculture press, BeiJing, China. 